Dehtiarov Vladislav. Considered Ontogenetic Structure Cenopopulations. Acer platanoides in nine forest phytocenoses, typical of the Krolevetsky-Glukhovski geo-botanical districts. Characteristic features of Acer platanoides ontogenetic spectrum in terms of this district.

Key words: forest phytocenosises population, Acer platanoides, Krolevetsky-Glukhiv geobotanic region.

Стаття надійшла до редколегії 26.11.2015 p.

УДК 574.3. 3.504

Ігор Коваленко

\title{
Особливості популяційної організації домінантів трав'янистого ярусу лісових екосистем Національного природного парку «Деснянсько-Старогутський» (на основі віталітетного аналізу)
}

Віталітетна структура популяції - це її важлива характеристика. Дослідженнями охоплено популяції п’яти видів рослин лісових екосистем Національного природного парку «Деснянсько-Старогутський»: Aegopodium podagraria L., Asarum europaeum L., Carex pilosa Scop., Molinia caerulea (L.) Moench., Stellaria holostea L. Порівняльний аналіз віталітетної структури популяцій клоноутворювальних рослин трав'янистого ярусу в лісових асоціаціях засвідчує, що їхні віталітетні спектри широко варіюють, а це вказує на чутливість віталітетної структури популяцій до еколого-ценотичних умов й обумовлює високу інформативну цінність віталітетного аналізу. Одержані оцінки віталітетної структури популяцій досліджуваних видів, які є домінантами в лісових екосистемах Національного природного природного парку «Деснянсько-Старогутський», можуть бути вихідними показниками під час організації моніторингу в цьому національному парку та для порівняння стану популяцій до уведення режиму заповідності та після.

Ключові слова: лісові екосистеми, віталітетний аналіз, популяції.

Постановка наукової проблеми та їі значення. Теоретичні основи й алгоритм віталітетного аналізу сформульовано Ю. А. Злобіним [4]. Віталітетний аналіз має на меті оцінку життєздатності особин рослин на основі морфогенетичних ознак із подальшим установленням співвідношення в популяції кількості особин різної життєздатності. В основі віталітетного аналізу лежить ідея про те, що продукційний процес, ріст і морфологічна структура особини, виявлені в кількісних оцінках, дають узагальнену оцінку їі життєвого стану.

Віталітетна структура популяції - важлива характеристика. В останні десятиріччя віталітетний аналіз усе ширше застосовують у популяційних дослідженнях і він виявляється високоінформативним щодо стану популяцій рослин $[1,7,9]$.

Г. Г. Жиляєв та I. В. Царик [3] справедливо відзначали, що «здатність до модифікації онтогенезу виступає найважливішим механізмом забезпечення стійкості популяцій». За рахунок цієї модифікації морфологічної структури особин рослин змінюються їхні віталітетні стани, що робить аналіз віталітетної структури популяцій найціннішим інструментом для індикації їхнього статусу в різних угрупованнях. Віталітетний аналіз дав змогу також ефективно порівнювати стан різних популяцій між собою [5].

Мета й завдання статті. Мета досліджень - визначення віталітетного стану популяцій рослин трав' янистого ярусу з подальшим їх порівнянням.

Головні завдання статті: а) зібрати базу даних морфометричних вимірювань рослин із різних фітоценозів; б) на основі отриманих даних провести віталітетний аналіз і визначити стан та структуру популяцій досліджуваних видів; в) здійснити порівняльний аналіз за показниками віталітету для популяцій із різних фітоценозів.

Виклад основного матеріалу й обгрунтування отриманих результатів дослідження. Дослідженнями охоплено популяції п’яти видів рослин лісових екосистем Національного природного парку

(C) Коваленко I., 2015 
«Деснянсько-Старогутський»: Aegopodium podagraria L., Asarum europaeum L., Carex pilosa Scop., Molinia caerulea (L.) Moench., Stellaria holostea L.

Здійснюючи аналіз, особини в популяціях за їхнім віталітетом поділяють на три категорії якості: високої (А), проміжної (В) та нижчої (С). Цей поділ виконують на основі ключових, або детермінуючих, віталітет особини морфоструктурних ознак. Звичайно виокремлюють три такі ознаки. Установлення ключових ознак - це самостійне завдання. Під час його розв'язання оцінюють: а) біологічне значення кожної з ознак для цієї біоморфи; б) ступінь мінливості ознаки від особини до особини, уважаючи, що більш варіюючі ознаки мають велику інформативність; в) ступінь скорельованості ознак між собою, прагнучи до того, щоб ознаки, віднесені до складу ключових, не мали високої скорельованості й не належали до однієї кореляційної плеяди; г) факторні навантаження ознак, одержувані в ході факторного аналізу, вибираючи їх так, щоб ознаки 3 найбільш високими факторними навантаженнями входили до складу ключових.

Залежно від співвідношення в популяції особин різного віталітету популяції оцінюють як процвітаючі, рівноважні або депресивні. Інтегральною оцінкою якості популяцій є індекс $\mathrm{Q}(\mathrm{Q}=1 / 2$ $(\mathrm{a}+\mathrm{b}))$, величина якого перебуває в амплітуді від 0 до 0,5.

Для встановлення віталітетної структури популяцій існують формалізований алгоритм i спеціальна комп'ютерна програма, що дають змогу поетапно виходити на повний віталітетний аналіз. У наших дослідженнях віталітетний аналіз проводимо за повною схемою, реалізацію якої подано нижче на прикладі трьох популяцій A. podagraria з трьох різних асоціацій.

У період польових досліджень для віталітетного аналізу зроблено рандомізовану вибірку особин (парціальних кущів A. podagraria) загальним обсягом 130 шт. в асоціаціях: I. Quercetum corylosoaegopodiosum (41 особина); II. Querceto-Pinetum coryloso-aegopodiosum (45 особин); III. BetuletoPinetum coryloso-aegopodiosum (44 особини).

У кожної особини A. podagraria враховувалося по 12 морфоструктурних параметрів: надземна фітомаса (W), висота (H), розмір листкової поверхні (A), фітомаса листків (WL), фітомаса плодів (WFR), кількість плодів (NFR), а також шість алометричних параметрів: RE1, RE2, LAR, SLA, LWR, HWR.

При камеральній комп'ютерній обробці три вибірки об'єднано в одну загальну й для кожного 3 морфопараметрів обчислено середне арифметичне, стандартне відхилення, стандартну похибку та коефіцієнт варіації. Ці дані свідчать, що мінливість значень різних ознак неоднакова й перебуває в широкій амплітуді варіювання від 8 до $68 \%$. Найбільш мінливими з них виявилися репродуктивне зусилля та загальна фітомаса.

На наступному етапі обчислено коефіцієнти парної кореляції між розглянутими 12-ма параметрами, а на їх основі складено кореляційні плеяди.

Об’єднану вибірку особин також використано для факторного аналізу. Ознаками з найбільшими факторними навантаженнями за трьома виділеними чинниками, які охопили 70 \% загальної дисперсії, виявилися фітомаса листків, розмір листкової поверхні, фітомаса генеративних органів, загальна фітомаса й репродуктивне зусилля (RE1).

Ураховуючи всю отриману інформацію, за ознаки діагностуючих віталітет особин A. podagraria взято загальну фітомасу, розмір листкової поверхні та репродуктивне зусилля (RE1). Їх використано для оцінки статусу особин у популяціях і визначення віталітетного стану популяцій.

Аналогічно встановлено ключові морфопараметри, які діагностують віталітет особин, $\mathrm{i}$ для всіх інших досліджуваних видів трав'янистого ярусу в лісових асоціаціях на північному сході України. Для аналізу морфогенетичної структури особин досліджуваних рослин використовували не менше 11-12 морфометричних ознак.

Aegopodium podagraria L. Як вказано вище, для аналізу віталітетної структури популяцій A. podagraria використано вибірку зі 130 парціальних кущів. Як ключові параметри віталітету застосовано загальну фітомасу особини, розмір листкової поверхні й репродуктивне зусилля. Статистична достовірність отриманих даних досить висока та складає не менше 70-90\%.

Популяція A. podagraria 3 Querceto-Pinetum coryloso-aegopodiosum виявилася за віталітетною структурою процвітаючою $з$ індексом якості $\mathrm{Q}=0,409,3$ Quercetum coryloso-aegopodiosum рівноважною з індексом якості Q, що дорівнює 0,200, а з Betuleto-Pinetum coryloso-aegopodiosum депресивною при $\mathrm{Q}=0,093$. Відповідно, у цьому ряді популяцій зменшувалася частка особин вищого класу А та збільшувалася частка особин нижчого класу С. 
Asarum europaeum L. Аналіз віталітетної структури популяцій A. europaeum проведено на основі вибірки зі 187 парціальних кущів, у тому числі в асоціаціях: I. Quercetum coryloso-asarosum (66 особин), II. Pinetum coryloso-asarosum (61 особина), III. Querceto-Pinetum asarosum (60 особин).

Ключовими ознаками віталітету виявилися загальна фітомаса $(\mathrm{W})$, розмір листкової поверхні (A) і репродуктивне зусилля (RE1).

Із трьох вивчених популяцій $A$. еuropaеuт одна з асоціації Quercetum coryloso-asarosum виявилася процвітаючою з коефіцієнтом якості $\mathrm{Q}=0,346$, а дві інші - рівноважними зі значеннями $\mathrm{Q}$, що, відповідно, дорівнюють 0,207 і 0,292. Статистична вірогідність отриманих оцінок лежала в амплітуді від 50 до 99,5\%.

Потрібно зазначити, що популяція A. europaeum нижчого віталітету з асоціації Querceto-Pinetum asarosum $€$ найстарішою щодо онтогенетичного складу й найвищого індексу генеративності в $68 \%$.

Очевидно, віталітетна структура популяцій копитняка має тенденцію до зниження в міру старіння популяцій.

Carex pilosa Scop. Аналіз віталітетної структури популяцій $C$. pilosa проведено на основі вибірки у 135 парціальних кущів, в асоціаціях: I. Querceto-Pinetum caricosum (47 особин), II. Quercetum coryloso-caricosum (43 особини), III. Betuleto-Quercetum coryloso-caricosum (45 особин).

Ключовими ознаками для визначення віталітету особин $C$. pilosa виявилися загальна фітомаса $(\mathrm{W})$, розмір листкової поверхні (A) й репродуктивне зусилля (RE1).

Статистична достовірність отриманих оцінок перебувала в амплітуді від 50 до 92,5 \%. Популяції C. pilosa в першій із двох розглянутих лісових асоціацій були рівноважними, з індексом якості Q, що дорівнював, відповідно, 0,250 і 0,239. Їх віталітет був практично однаковим, лише в асоціації Quercetum coryloso-caricosum дещо вища частка парціальних кущів осоки вищого класу віталітету. На відміну від цього, популяція C. pilosa 3 асоціації Querceto-Pinetum caricosum була депресивною 3 індексом якості $\mathrm{Q}$, що дорівнював 0,163 . Як і у випадку з копитняком, виявилося, що ця остання популяція за онтогенетичним складом особин $є$ найстарішою.

Molinia caerulea (L.) Moench. Аналіз віталітетної структури популяцій M. caerulea проведено на основі вибірки зі 100 парціальних кущів в асоціаціях: I. Pinetum moliniosum (32 особини), II. Querceto-Pinetum frangulloso-molinioso-hylocomiosum (37 особин), III. Betuleto-Pinetum moliniosum (31 особина).

Ключовими ознаками для визначення віталітету M. caerulea виявилися такі: загальна надземна фітомаса (W), розмір листкової поверхні (A) та репродуктивне зусилля (RE1).

Статистична достовірність отриманих оцінок перебувала в амплітуді від 50 до 80 \%. Дві популяції з асоціацій Querceto-Pinetum frangulloso-molinioso-hylocomiosum i Betuleto-Pinetum molinoisum виявилися за віталітетним складом рівноважними з індексами якості $\mathrm{Q}$, що дорівнювали, відповідно, 0,181 і 0,250.

Популяція з Pinetum molinoisum віднесена до категорії депресивних, тому що індекс якості для неї становить 0,145 . Онтогенетична структура розглянутих популяцій M. caerulea була подібною. Дані щодо віталітетної структури уточнюють статус цих популяцій і показують, що популяція M. caerulea в Pinetum molinoisum найвіддаленіша від еколого-фітоценотичного оптимуму.

Stellaria holostea L. Віталітетна структура популяцій S. holostea установлена на основі вибірки в 102 парціальних кущів у трьох лісових асоціаціях: I. Querceto-Pinetum coryloso-stellariosum (37 особини), II. Quercetum coryloso-caricoso-stellariosum (33 особини), III. Querceto-Pinetum stellariosum (32 особини).

Як ключові ознаки віталітету особин узято загальну фітомасу особини (W), розміри листкової поверхні (A) і репродуктивного зусилля (RE2).

Статистична вірогідність отриманих оцінок перебувала в амплітуді від 50 до $80 \%$. Із трьох популяцій S. holostea дві виявилися рівноважними з індексом якості в 0,236 і 0,226, а одна - депресивною з індексом якості 0,156. Депресивна популяція S. holostea зростала в асоціації Quercetum coryloso-caricoso-stellariosum. За віковим складом це була найстаріша популяція з найбільшим значенням коефіцієнта віковості. У цьому випадку також спостерігали сполучення підвищеної віковості популяції з її депресивною віталітетною структурою.

Висновки та перспективи подальшого дослідження. Одержані оцінки віталітетної структури популяцій клоноутворювальних рослин трав'янистого ярусу лісів північного сходу України можна вважати цілком надійними, оскільки вони грунтуються, загалом, на повному аналізі морфологічної 
структури понад 600 особин досліджуваних видів рослин. Статистична достовірність оцінок віталітетної структури популяцій переважно перебуває в амплітуді 70-99 \% і лише в окремих випадках нижче $70 \%$.

Порівняльний розгляд віталітетної структури популяцій клоноутворювальних рослин трав'янистого ярусу в лісових асоціаціях засвідчує, що їхні віталітетні спектри широко варіюють: індекс якості Q популяцій перебуває в амплітуді від 0,000 до 0,500, тобто охоплює повний теоретично можливий розмах значень цього коефіцієнта, що свідчить про чутливість віталітетної структури популяцій до еколого-ценотичних умов й обумовлює високу інформативну цінність віталітетного аналізу. Із розглянутих популяцій рослин трав'янистого ярусу процвітаючими виявилися дві популяції: одна популяція A. podagraria в асоціації Querceto-Pinetum coryloso-aegopodiosum, одна - A. europaeum - 3 асоціації Quercetum coryloso-asarosum.

Оскільки віталітетний аналіз грунтується на інформації й морфологічній структурі особин рослин, він досить точно відображає ступінь відповідності еколого-фітоценотичних умов для рослин цього виду. Так, наприклад, простежено, що в Convallaria majalis L. i Maianthemum bifolium (L.) F. W. Schmidt перша реакція на екологічне й ценотичне пригнічення виявляється в погіршенні всіх морфологічних та ростових параметрів рослин, хоча чисельність особин у популяціях може навіть зростати [6]. У літературі наведено безліч інших даних про обумовленість морфологічного статусу рослин умовами їх зростання. Узагальнюючи дані й спираючись на принцип алокації, М. Г. Баштовий [2] стверджував, що зменшення розмірів особин і скорочення в них метамерів є вираженням адаптації рослин до стресових умов. Наші матеріали повністю підтверджують цю думку.

Рівень віталітету популяцій виявився статистично вірогідно пов'язаним із такими ценотичними чинниками, як вік і зімкнутість деревостану. Віталітет популяцій збільшується з віком і зімкнутістю деревостану, досягаючи максимуму в лісових асоціаціях, де вік лісоутворювальної деревної породи становить 75-85 років, а зімкнутість деревного пологу - 0,75-0,85. Раніше О. В. Морозовим [8] показано зв' язок брусниці зі зрілими зімкнутими лісами. Нами цю закономірність доведено для всіх бореальних рослин. Результат показує, що вивчені клоноутворювальні трави нижнього ярусу лісу типові лісові види, адаптовані до затінення й кореневої конкуренції з деревостаном.

Одержані оцінки віталітетної структури популяцій досліджуваних видів, які є домінантами в лісових екосистемах Національного природного природного парку «Деснянсько-Старогутський», можуть бути вихідними показниками при організації моніторингу в цьому національному парку й для порівняння стану популяцій до уведення режиму заповідності та після цього.

\section{Джерела та література}

1. Бариева Э. Р. Виталитетный состав популяций Amaranthus retroflexus L. в посадках картофеля и на залежи / Э. Р. Бариева // Растительные ресурсы, 1999. - Т. 35, № 3. - С. 61-67.

2. Баштовой Н. Г. Стратегия защиты у ценопопуляций сныти обыкновенной и купены лекарственной в условиях антропогенных нагрузок / Н. Г. Баштовой // Популяции растений: принципы организации и проблемы охраны природы. - Йошкар-Ола, 1991. - С. 67.

3. Жиляев Г. Г. Структура популяций травянистых растений в растительных сообществах Карпат / Г. Г. Жиляев, И. В. Царик // Ботанический журн. - 1989. - Т. 74, № 1. - С. 88-95.

4. Злобин Ю. А. Теория и практика оценки виталитетного состава ценопопуляций растений / Ю. А. Злобин // Ботанический журн. - 1989. - Т. 74, № 6. - С. 769-781.

5. Злобин Ю. А. Популяционная экология растений: современное состояние, точки роста / Ю. А. Злобин. Сумы : Унив. книга, 2009. - 263 с.

6. Крылова И. Л. Влияние экологических факторов на ценопопуляции некоторых лекарственных растений / И. Л. Крылова // Экологические исследования в Москве и Московской области: состояние растительного покрова. - М., 1992. - С. 98-104.

7. Кучер Е. Анализ виталитетного состава популяций Dactilorhiza romana (seb. et Mauri) / E. Кучер // Актуальні проблеми ботаніки та екології. - Киев, 2000. - С. 69-70.

8. Морозов О. В. Состояние брусничников в лесах Белоруси / О. В. Морозов // Состав и мониторинг лесов на рубеже XXI века. - Минск, 1998. - С. 221-223.

9. Семкин Б. И. Оценка жизненного состояния популяций Dimeria neglecta (Рoaceae) на островах Русском и Путятина (Дальний Восток, Россия) / Б. И. Семкин, Г. Ю. Ким, Л. М. Борзова // Ботанический журн. 1995. - Т. 80, № 11. - С. 84-88.

Коваленко Игорь. Особенности популяционной организации доминантов травянистого яруса лесных экосистем Национального природного парка «Деснянско-Старогутский» (на основе виталитетного анализа). 
Виталитетная структура популяции является ее важной характеристикой. Исследованиями охвачены популяции пяти видов растений лесных экосистем Национального природного парка «Деснянско-Старогутский»: Aegopodium podagraria L., Asarum europaeum L., Carex pilosa Scop., Molinia caerulea (L.) Moench., Stellaria holostea L. Cpaвнительный анализ виталитетной структуры популяций клонообразующих растений травянистого яруса в лесных ассоциациях показывает, что их виталитетные спектры широко варьируют, а это свидетельствует о чувствительности виталитетнои структуры популяций к эколого-ценотическим условиям и обусловливает высокую информативную ценность виталитетного анализа. Полученные оценки виталитетной структуры популяций исследуемых видов, которые являются доминантами в лесных экосистемах Национального природного парка «Деснянско-Старогутский», могут быть исходными показателями при организации мониторинга в этом национальном парке и для сравнения состояния популяций до введения режима заповедности и после.

Ключевые слова: лесные экосистемы, виталитетный анализ, популяции.

Kovalenko Igor. Features Population Structure of Dominant Herbaceous Tier in Forest Ecosystems of National Natural Park «Desnyansko-Starogutsky» (on the Basis of Vitality Analysis). Population studies include many ways with the help of which one can evaluate the status of populations. One of the most promising and generally accepted ways is vitality analysis. Vitality analysis is undertaken to assess the viability of plant species on the basis of morphogenetic characteristics with the subsequent setting up of the ratio in the number of individuals of different vitality in a population. The basis of vitality analysis is the idea that a production process, growth and morphological structure of species defined in quantitative assessments provide a summary evaluation of its vital state. The goal of our study is to make vitality analysis of populations of five species of dominant herbaceous tier that grow in National Natural Park «Desnyansko-Starogutsky»: Aegopodium podagraria L., Asarum europaeum L., Carex pilosa Scop., Molinia caerulea (L.) Moench., Stellaria holostea L. The resulting estimates of the vitality structure of populations of clone formative plants of subshrub layer of forests of the North-East of Ukraine can be considered quite reliable because they are based, in general, on the complete analysis of the morphological structure of 600 individuals of the species studied. The statistical reliability of the estimates of vitality structure of populations is primarily in the amplitude of 70-99 \%, and only in some cases - below $70 \%$.

Key words: vitality structure, populations, forest ecosystems.

Стаття надійшла до редколегії 11.10.2015 p.

\section{Деревний попіл як засіб зниження переходу ${ }^{137} \mathrm{Cs}$ із грунту в рослини горобини звичайної (Sorbus aucuparia L.) та крушини ламкої (Rhamnus frangula L.) в лісових екосистемах Полісся України}

Показано вплив деревного попелу на перехід ${ }^{137} \mathrm{Cs}$ із грунту в молоді пагони й листя горобини звичайної та крушини ламкої протягом періоду вегетації в лісових екосистемах Полісся України, забруднених радіонуклідами в результаті аварії на Чорнобильській АЕС. Здійснено порівняльний аналіз ефективності застосування калійного добрива, деревного попелу і їх поєднання як засобів зниження переходу радіоцезію з грунту в рослини в перший та другий рік після внесення.

Ключові слова: Sorbus aucuparia L., Rhamnus frangula L., ${ }^{137} \mathrm{Cs}$, період вегетації, деревний попіл, калійне добриво.

Постановка наукової проблеми та ії значення. Чорнобильська катастрофа істотно вплинула на стан довкілля більшості європейських країн. За підрахунками експертів, під час вибуху на четвертому енергоблоці ЧАЕС в атмосферу викинуто радіонукліди сумарною активністю понад 50 MКi. Лише випадіння радіоактивного цезію $\left({ }^{137} \mathrm{Cs}\right)$ становили 15 ПБк у Білорусі, 13 ПБк в Україні й 29 ПБк у Росії. Решта, 27 ПБк, - в інших європейських країнах [1, с. 14-15]. Основний удар радіоактивного забруднення прийняли ліси, зігравши роль природних фільтрів. Оскільки масштабні контрзаходи в лісових екосистемах вивчалися мало та майже не проводились, останні й досі

() Мандро Ю., Вінічук М., 2015 